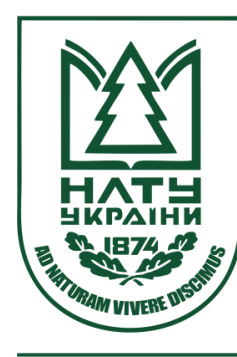

Науковий вісник НЛТУ України Scientific Bulletin of UNFU

https://nv.nltu.edu.ua

https://doi.org/10.36930/40300108

$@ \bowtie$ Correspondence author

Article received 21.01.2020 p.

Article accepted 27.02.2020 p.

M. H. Rumiantsev

UDK 630.5:633.872.1

М. Г. Румянцев

Український ордена "Знак почани" науково-дослідний інститут лісового господарства і агролісомеліорації ім. Г. М. Височького, м. Харків, Україна

\title{
СТРУКТУРНО-ФУНКЦІОНАЛЬНИЙ РОЗПОДІЛ ДУБОВИХ НАСАДЖЕНЬ ЛІВОБЕРЕЖНОГО ЛІСОСТЕПУ
}

\begin{abstract}
За матеріалами лісовпорядкування (таксаційної повидільної бази даних) проведено розподіл загальної площі вкритих лісовою рослинністю лісових ділянок у межах Лівобережного Лісостепу за панівними породами. Проаналізовано розподіл площі та запасу дубових насаджень за категоріями лісів та їхню вікову структуру в розрізі походження. Виявлено, що видовий склад головних лісотвірних порід у лісах Лівобережного Лісостепу є доволі різноманітним і представлений загалом 70 деревними видами. Найпоширенішими є насадження за участю дуба звичайного (Quercus robur L.), які займають 46,4 \% (284,1 тис. га) від загальної площі вкритих лісовою рослинністю лісових ділянок. Результати проведених досліджень свідчать, що найбільша частка від загальної площі дубових лісів Лівобережного Лісостепу припадає на рекреаційно-оздоровчі ліси - 38,7 \% (109,7 тис. га), дещо меншою - 28,1 \% (79,9 тис. га) - є частка захисних лісів, а частка експлуатаційних лісів і лісів природоохоронного, наукового, історико-культурного призначення становить $18,2 \%$ (51,8 тис. га) та $15,0 \%$ (42,7 тис. га) відповідно. Розподіл загального запасу дубових лісів у межах категорій лісів приблизно такий самий, як і за площею. В усіх категоріях лісів виявлено розбалансованість вікової структури дубових насаджень із істотним переважанням середньовікових і пристиглих насаджень, доволі значною часткою стиглих і перестійних насаджень та незначною часткою молодняків. Віднесення кожної окремої лісової ділянки дубових насаджень до певної категорії лісів зумовлює встановлення відповідного режиму лісокористування, насамперед виконання відповідних видів рубок. Для ефективного ведення лісового господарства, зокрема, в дубових лісах Лівобережного Лісостепу, доцільним $є$ поліпшення вікової структури цих насаджень із урахуванням їхнього функціонального призначення, що визначається їх належністю до певної категорії лісів.
\end{abstract}

Ключові слова: дуб звичайний (Quercus robur L.); категорії лісів; походження насадження; групи віку; запас насадження; матеріали лісовпорядкування.

Вступ. Лісам належить визначальна роль у підтримці стабільності біосфери завдяки глобальному їх впливу на клімат усієї планети. Лісові насадження є ключовими елементами стабілізації ландшафтів $[1,6,7,10]$.

У лісовому фонді країни, підпорядкованому Державному агентству лісових ресурсів України, одними 3 найбільш цінних $є$ дубові насадження, площа яких становить близько 28 \% (1,7 млн га) від загальної площі лісів [12]. Дубові ліси виконують надзвичайно важливі еколого-захисні та рекреаційно-оздоровчі функції, а також задовольняють потреби народного господарства в цінній деревині як на місцевому, так і на регіональному рівнях [14].

Структурно-функціональний розподіл лісів $\epsilon$ важливим підгрунтям під час розроблення відповідних заходів щодо забезпечення збалансованого багатоцільового використання лісових екосистем 3 урахуванням їхньої видової та вікової структури. Розподіл лісів за групами віку об'єднує календарний і біологічний віки. "Нормальним" вважається ліс, який рівномірно представлений всіма класами віку та віковими групами - від молодняків до стиглих і перестійних насаджень [5].

Для визначення режиму користування та ефективно- го ведення лісового господарства, зокрема, в дубових лісах Лівобережного Лісостепу, доцільним $є$ поліпшення вікової структури цих насаджень із урахуванням їхнього функціонального призначення, що визначається їх належністю до певної категорії лісів.

Аналіз літературних джерел. Дубові насадження Лівобережного Лісостепу доволі широко охарактеризували вітчизняні дослідники за багатьма лісівничими напрямами. Так, зокрема, їхній сучасний стан, продуктивність та показники використання ними лісорослинного потенціалу вивчали В. П. Ткач та ін. [15]; санітарний стан після вживання лісогосподарських заходів В. Л. Мєшкова [9]; особливості проведення доглядових рубань - Л. С. Луначевський та М. Г. Румянцев [8], а лісовідновних рубок - В. П. Ткач та ін. [17]; особливості формування попереднього та наступного природного поновлення господарсько цінних порід у дубових ліcax - В. П. Ткач та ін. [16], М. Г. Румянцев та ін. [12, 11], М. М. Діденко та О. К. Поляков [2]. Однак, незважаючи на це, актуальним залишається питання щодо структурно-функціонального розподілу та вікової структури дубових лісів.

Об'єкт дослідження - дубові насадження різного

Інформація про авторів:

Румянцев Максим Григорович, канд. с.-г. наук, ст. наук. співробітник, лабораторія лісівництва.

Email: maxrum-89@ukr.net; https://orcid.org/0000-0002-2245-2441

Цитування за ДСтУ: Румянцев М. Г. Структурно-функціональний розподіл дубових насаджень Лівобережного Лісостепу. Науковий вісник НЛТУ України. 2020, т. 30, № 1. С. 49-54.

Citation APA: Rumiantsev, M. H. (2020). The structural and functional distribution of oak stands of Left-bank Forest-steppe zone. Scientific Bulletin of UNFU, 30(1), 49-54. https://doi.org/10.36930/40300108 
походження (порослевого, насіннєвого природного та насіннєвого штучного) всіх наявних категорій лісів на площі майже 284,1 тис. га, підпорядкованих Державному агентству лісових ресурсів України.

Предмет дослідження - структурний та функціональний розподіли дубових лісів у межах Лівобережного Лісостепу, а також їхній розподіл за походженням та віковою структурою.

Мета дослідження - проаналізувати структурно-функціональний розподіл дубових лісів Лівобережного Лісостепу та їхню вікову структуру в розрізі походження насаджень.

Для досягнення поставленої мети потрібно виконати такі основні завдання:

- проаналізувати розподіл вкритих лісовою рослинністю лісових ділянок у межах Лівобережного Лісостепу за панівними лісотвірними породами;

• вивчити функціональний розподіл загальної площі дубових лісів (їхня належність до певної категорії);

- проаналізувати вікову структуру дубових насаджень Лівобережного Лісостепу в розрізі категорій лісів та їхнього походження;

- надати пропозиції щодо вживання відповідних заходів із забезпечення збалансованого багатоцільового використання лісових екосистем $з$ урахуванням їхньої видової та вікової структури.

Наукова новизна дослідження - вперше для умов Лівобережного Лісостепу проаналізовано вікову структуру дубових насаджень в розрізі їхнього походження та категорій лісів. Уточнено дані щодо розподілу вкритих лісовою рослинністю лісових ділянок регіону досліджень за панівними лісотвірними породами.

Практична значущість отриманих результатів полягає в розробленні основних положень (на основі структурно-функціонального розподілу лісів) щодо відповідних заходів із забезпечення збалансованого багатоцільового використання лісових екосистем з урахуванням їхньої видової та вікової структури. Встановлено, що для ефективного ведення лісового господарства в дубових лісах необхідним $є$ вживання відповідних господарських заходів щодо поліпшення вікової структури цих насаджень із обов'язковим урахуванням їхнього функціонального призначення (їхня належність до певної категорії лісів).

Матеріали і методи дослідження. Матеріали лісовпорядкування були основою для проведення розрахунків. Загалом було проаналізовано близько 69,7 тис. таксаційних виділів дубових насаджень різного походження в межах Лівобережного Лісостепу. Площа досліджуваних насаджень становила майже 284,1 тис. га. Поділ лісів на категорії, умови та ознаки віднесення їх до категорій лісів, а також виділення особливо захисних лісових ділянок із режимом обмеженого користування, здійснювали відповідно до "Порядку поділу лісів на категорії та виділення особливо захисних лісових ділянок" [13]. Розподіл вікової структури дубових насаджень за площею і запасом деревини в розрізі категорій лісів проводили за загальноприйнятими в лісовій таксації методиками $[3,4]$.

Охоплено лісовий фонд 29 державних підприємств лісового господарства в межах Київського та по м. Києві (2 підприємства), Полтавського (8 підприємств), Сумського (9 підприємств), Харківського (6 підприємств), Черкаського (1 підприємство) та Чернігівсь- кого (3 підприємства) обласних управлінь лісового та мисливського господарства.

Результати дослідження та їх обговорення. Аналіз матеріалів лісовпорядкування свідчить, що видовий склад головних лісотвірних порід у лісах Лівобережного Лісостепу є доволі різноманітним і представлений загалом 70 деревними видами. Найпоширенішими є насадження за участю дуба звичайного (Quercus robur L.), які займають 46,4 \% (284,1 тис. га), сосни звичайної (Pinus sylvestris L.) - 31,3 \% або 191,7 тис. га, вільхи чорної (Alnus glutinosa (L.) Gaerth.) - 5,3 \% або 32,2 тис. га, ясена звичайного (Fraxinus excelsior L.) - 3,2 \% або 19,3 тис. га, берези повислої (Betula pendula Roth.)2,9\% або 18,0 тис. га та інших видів (рисунок).

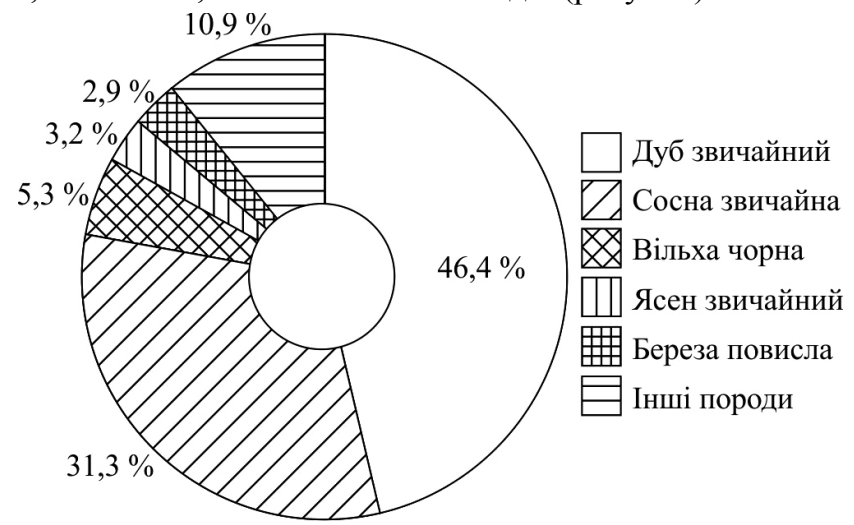

Рисунок. Розподіл площі вкритих лісовою рослинністю лісових ділянок Лівобережного Лісостепу за панівними лісотвірними породами, \%

Досліджувані дубові насадження, окрім задоволення потреб народного господарства в цінній дубовій деревині, виконують надзвичайно важливі екологічні, захисні та рекреаційно-оздоровчі функції.

Внаслідок проведеного аналізу матеріалів лісовпорядкування виявлено, що найбільша частка від загальної площі дубових лісів Лівобережного Лісостепу припадає на рекреаційно-оздоровчі ліси - 38,7 \% (109660 га), дещо меншою - 28,1 \% (79915 га) - $\epsilon$ частка захисних лісів, а частка експлуатаційних лісів і лісів природоохоронного, наукового, історико-культурного призначення становить 18,2 \% (51790 га) та 15,0\% (42729 га) відповідно (табл. 1). Розподіл загального запасу дубових лісів у межах категорій лісів приблизно такий самий, як і за площею.

До категорії експлуатаційних лісів належать лісові ділянки дубових насаджень, не зайняті лісами природоохоронного, наукового, історико-культурного призначення, рекреаційно-оздоровчими та захисними (категорії лісів 3 особливим режимом лісокористування) i призначені для задоволення потреб національної економіки в деревині (The procedure, 2007), заготовленої в порядку виконання рубок головного користування. Загальна площа дубових насаджень в межах експлуатаційних лісів Лівобережного Лісостепу загалом становить 51790 га.

Серед захисних лісів, що мають особливо важливе значення для захисту навколишнього природного середовища від несприятливої дії абіотичних та біотичних чинників, найбільша частка від загальної площі лісів категорії припадає на ліси, що мають важливе значення для захисту навколишнього природного середовища $57,5 \%$ або 45954 га; смуги лісів вздовж річок, навколо озер та ін. водойм (21,7 \% або 17321 га); протиерозійні 
ліси (18,6 \% або 14881 га); захисні смуги лісів вздовж залізниць (1,6\% або 1259 га); захисні смуги лісів вздовж автомобільних доріг державного значення
(0,4\% або 315 га) та державні захисні лісові смуги $(0,2 \%$ або 184 га).

Табл. 1. Розподіл площі та запасу дубових насаджень Лівобережного Лісостепу за категоріями лісів

\begin{tabular}{|c|c|c|c|c|c|}
\hline \multirow{2}{*}{ Категорія лісів } & \multicolumn{2}{|c|}{ Площа } & \multicolumn{3}{|c|}{ Запас } \\
\hline & га & $\%$ & тис. $\mathrm{M}^{3}$ & $\%$ & $\mathrm{~m}^{3} / \Gamma \mathrm{a}$ \\
\hline \multicolumn{6}{|c|}{ Експлуатаційні ліси } \\
\hline Усього & 51790 & 18,2 & 13342,3 & 18,9 & 258 \\
\hline \multicolumn{6}{|c|}{ Захисні ліси } \\
\hline Державні захисні лісові смуги & 184 & 0,1 & 29,6 & - & 161 \\
\hline Захисні смуги лісів вздовж автом. доріг державного значення & 315 & 0,1 & 83,3 & 0,1 & 264 \\
\hline Захисні смуги лісів вздовж залізниць & 1259 & 0,4 & 329,1 & 0,5 & 261 \\
\hline Інші ліси, що мають важливе знач. для захисту природного серед. & 45954 & 16,2 & 10882,3 & 15,4 & 237 \\
\hline Ліси протиерозійні & 14881 & 5,2 & 3209,4 & 4,5 & 216 \\
\hline Смуги лісів вздовж річок, навколо озер, водойм та ін. & 17321 & 6,1 & 4366,4 & 6,2 & 252 \\
\hline $\begin{array}{c}\text { Усього } \\
\end{array}$ & 79915 & 28,1 & 18900,0 & 26,7 & 237 \\
\hline \multicolumn{6}{|c|}{ Ліси природоохоронного, наукового, історико-культурного призначення } \\
\hline Заповідні лісові урочища & 3938 & 1,4 & 962,6 & 1,4 & 244 \\
\hline Ліси, що мають наукове або історичне значення & 188 & 0,1 & 37,6 & 0,1 & 200 \\
\hline Національні природні парки (господарська зона) & 3342 & 1,2 & 845,3 & 1,2 & 253 \\
\hline Національні природні парки (заповідна зона) & 1170 & 0,4 & 339,7 & 0,5 & 290 \\
\hline Національні природні парки (зона регульованої рекреації) & 1370 & 0,5 & 370,8 & 0,5 & 271 \\
\hline Національні природні парки (зона стаціонарної рекреації) & 6 & - & 1,5 & - & 266 \\
\hline Особливо цінні лісові масиви & 1512 & 0,5 & 461,2 & 0,7 & 305 \\
\hline Пам'ятки природи & 26846 & 9,4 & 6973,0 & 9,9 & 260 \\
\hline Регіональні ландшафтні парки (господарська зона) & 1300 & 0,5 & 292,7 & 0,4 & 225 \\
\hline Регіональні ландшафтні парки (заповідна зона) & 1148 & 0,4 & 221,2 & 0,3 & 193 \\
\hline Регіональні ландшафтні парки (зона регульованої рекреації) & 1909 & 0,7 & 593,0 & 0,8 & 311 \\
\hline $\begin{array}{c}\text { Усього } \\
\end{array}$ & 42729 & 15,0 & 11098,8 & 15,7 & 260 \\
\hline \multicolumn{6}{|c|}{ Рекреаційно-оздоровчі ліси } \\
\hline Ліси 1 і 2 зон округів сан. охор. лікув.-оздор. територій & 35 & - & 6,5 & - & 186 \\
\hline Ліси 1 і 2 поясів зон саніт. охорони джерел водопостачання & 514 & 0,2 & 116,5 & 0,2 & 227 \\
\hline Ліси 3 зони округів сан. охорони лікув.-оздор. територій & 61 & - & 12,5 & - & 207 \\
\hline Ліси населених пунктів & 1494 & 0,5 & 354,6 & 0,5 & 237 \\
\hline Лісогосподарська частина лісів зелених зон & 39695 & 14,0 & 10671,4 & 15,1 & 269 \\
\hline Лісопаркова частина лісів зелених зон & 67861 & 23,9 & 16174,3 & 22,9 & 238 \\
\hline $\begin{aligned} \text { Усього } \\
\end{aligned}$ & 109660 & 38,7 & 27335,7 & 38,7 & 249 \\
\hline Разом за всіма категоріями лісів & 284094 & 100 & 70676,7 & 100 & 249 \\
\hline
\end{tabular}

Серед дубових лісів природоохоронного, наукового, історико-культурного призначення найбільшу площу займають пам'ятки природи (62,9 \% від загальної площі лісів категорії або 26846 га), національні природні парки (13,8\% або 5888 га) та регіональні ландшафтні парки (10,2\% або 4357 га). Заповідні лісові урочища займають 9,2 \% (3938 га), особливо цінні лісові масиви - 3,5 \% (1512 га), а ліси, що мають наукове або історичне значення, - лише $0,4 \%$ (188 га).

Дубові насадження в рекреаційно-оздоровчих лісах представлені лісопарковою (61,9\% або 67861 га) та лісогосподарською (36,2 \% або 39695 га) частинами лісів зелених зон, лісами в межах населених пунктів $(1,4 \%$ або 1494 га), а також лісами 1, 2 та 3 санітарних зон охорони лікувально-оздоровчих територій і джерел водопостачання - лише 0,5 \% (610 га) від загальної площі лісів категорії.

Найбільш продуктивними виявилися дубові насадження в межах лісів природоохоронного, наукового, історико-культурного призначення та експлуатаційних лісів (260 та $258 \mathrm{~m}^{3} \cdot \mathrm{ra}^{-1}$ ), менш продуктивними - в межах рекреаційно-оздоровчих та захисних лісів (249 та $\left.237 \mathrm{~m}^{3} \cdot \mathrm{ra}^{-1}\right)$. Разом за всіма категоріями лісів середній запас на 1 га дубових насаджень незалежно від їхнього походження сягає $249 \mathrm{~m}^{3} \cdot \mathrm{ra}^{-1}$.

Результати аналізу матеріалів лісовпорядкування щодо сучасного розподілу дубових насаджень за віком (табл. 2) свідчать про його розбалансованість із істотним переважанням як за площею, так і за запасом, середньовікових дубняків незалежно від їхнього походження.

В експлуатаційних лісах серед дубових насаджень майже половину загальної площі (45,8 \%) займають середньовікові насадження - 23737 га, а їхній запас сягає 6147,0 тис. ${ }^{3}$ (46,1 \% від загального запасу дубових лісів категорії). Майже третина загальної площі (31,4 \% або 16268 га) та запасом у 5101,6 тис. м $(38,2$ \%) займають пристиглі насадження. Частка площі стиглих і перестійних насаджень та молодняків $є$ майже однаковою та становить $11,1 \%$ (5726 га) та 11,7 \% (6060 га), а їхній запас - 1744,0 тис. $\mathrm{m}^{3}(13,1 \%)$ та 349,6 тис. $\mathrm{m}^{3}(2,6 \%)$ відповідно.

Серед дубняків в експлуатаційних лісах переважають насадження насіннєвого штучного (25963 га або 50,1 \% від загальної площі) та порослевого (20213 га або 39,0 \%) походження, а дубові насадження насіннєвого природного походження займають площу 5614 га (10,9 \%). Розподіл загального запасу дубняків у межах експлуатаційних лісів дещо відрізняється від розподілу за площею, оскільки найбільший запас6130,7 тис. м $^{3}$ або 45,9 \% - припадає на насадження порослевого походження, 41,8 \% або 5563,9 тис. ${ }^{3}-$ насіннєвого штучного та $12,3 \%$ або 1647,7 тис. ${ }^{3}$ - насіннєвого природного походження. 
Табл. 2. Вікова структура дубових насаджень Лівобережного Лісостепу в розрізі категорій лісів та їхнього походження

\begin{tabular}{|c|c|c|c|c|c|c|c|c|c|c|c|c|}
\hline \multirow{3}{*}{$\begin{array}{c}\text { Група віку дубових } \\
\text { насаджень }\end{array}$} & \multicolumn{3}{|c|}{ Порослеве } & \multicolumn{3}{|c|}{ Насіннєве природне } & \multicolumn{3}{|c|}{ Насіннєве штучне } & \multicolumn{3}{|c|}{$\begin{array}{c}\text { Разом } \\
\text { дубові насадження }\end{array}$} \\
\hline & \multirow{2}{*}{$\begin{array}{l}\text { площа, } \\
\text { га }\end{array}$} & \multicolumn{2}{|c|}{ запас } & \multirow{2}{*}{$\begin{array}{c}\text { площа, } \\
\text { га }\end{array}$} & \multicolumn{2}{|c|}{ запас } & \multirow{2}{*}{$\begin{array}{l}\text { площа, } \\
\text { га }\end{array}$} & \multicolumn{2}{|c|}{ запас } & \multirow{2}{*}{$\begin{array}{l}\text { площа, } \\
\text { га }\end{array}$} & \multicolumn{2}{|c|}{ запас } \\
\hline & & тис. $\mathrm{m}^{3}$ & $\mathrm{~m}^{3} / \Gamma \mathrm{a}$ & & тис. $\mathrm{M}^{3}$ & $\mathrm{~m}^{3} / \mathrm{гa}$ & & тис. $\mathrm{m}^{3}$ & $\mathrm{~m}^{3} / \Gamma \mathrm{a}$ & & тис. $\mathrm{M}^{3}$ & $\mathrm{~m}^{3} /$ га \\
\hline \multicolumn{13}{|c|}{ Експлуатаційні ліси } \\
\hline Молодняки & 37 & 2,7 & 74 & 56 & 6,7 & 119 & 5967 & 340,2 & 57 & 6060 & 349,6 & 58 \\
\hline Середньовікові & 4487 & 1255,5 & 280 & 1648 & 434,2 & 263 & 17602 & 4457,3 & 253 & 23737 & 6147,0 & 259 \\
\hline Пристиглі & 11829 & 35,6 & 316 & 2645 & 7,9 & 302 & 1794 & 568,1 & 317 & 16268 & 5101,6 & 314 \\
\hline Стиглі і перестійні & 3861 & 1136,9 & 294 & 1265 & 408,9 & 323 & 600 & 198,3 & 331 & 5726 & 1744,0 & 305 \\
\hline Усього & 20213 & 6130,7 & 303 & 5614 & 1647,7 & 293 & 25963 & 5563,9 & 214 & 51790 & 13342,3 & 258 \\
\hline \multicolumn{13}{|c|}{ Захисні ліси } \\
\hline & 220 & 25,3 & 115 & 21 & 1,5 & 72 & 4872 & 383,2 & 79 & 5113 & 409,9 & 80 \\
\hline Середн & 32806 & 17,4 & 266 & 3083 & 2,8 & 260 & 28119 & 6437,4 & 229 & 64008 & 15957,6 & 249 \\
\hline Пристиглі & 342 & 9,3 & 250 & 538 & 171,1 & 318 & 146 & 33,7 & 231 & 4526 & 1164,0 & 257 \\
\hline Стиглі та & 6038 & 1301,2 & 216 & 195 & 61,5 & 315 & 36 & 5,8 & 161 & 6269 & 1368,4 & 218 \\
\hline & 42906 & 11003,1 & 256 & 3836 & 1036,8 & 270 & 33173 & 6860,1 & 207 & 79915 & 18900,0 & 237 \\
\hline \multicolumn{13}{|c|}{ Ліси природоохоронного, наукового, історико-культурного призначення } \\
\hline Мол & 127 & 15,4 & 122 & 39 & 2,2 & 58 & 1364 & 100,1 & 73 & 1530 & 117,7 & 77 \\
\hline Середньовікові & 16927 & 710,0 & 278 & 3592 & 1028,5 & 286 & 10673 & 2621,5 & 246 & 31192 & 8360,0 & 268 \\
\hline Пристиглі & 3995 & & 279 & 850 & & 320 & 49 & 7,5 & 154 & 4894 & 93,8 & 285 \\
\hline Стиглі та & 546 & 70,1 & 235 & & 148,7 & 288 & 50 & 8,5 & 170 & 5113 & 1227,2 & 240 \\
\hline Усього & 25596 & 6909,7 & 270 & 4998 & 1451,6 & 290 & 12135 & 2737,5 & 226 & 42729 & 11098,8 & 260 \\
\hline \multicolumn{13}{|c|}{ Рекреаційно-оздоровчі ліси } \\
\hline Молодняки & 173 & 23,2 & 134 & 78 & 4,6 & 59 & 4309 & 261,3 & 61 & 4559 & 289,1 & 63 \\
\hline Середньовікові & 59021 & 15909,4 & 270 & 4600 & 1275,2 & 277 & 25566 & 5986,5 & 234 & 89187 & 23171,1 & 260 \\
\hline Пристиглі & 8416 & 2055,7 & 244 & 541 & 204,2 & 377 & 129 & 39,7 & 309 & 9086 & 2299,6 & 253 \\
\hline Стиглі та перестійні & 6587 & 1498,1 & 227 & 190 & 66,2 & 350 & 51 & 11,6 & 227 & 6827 & 1575,9 & 231 \\
\hline Усього & 74196 & 19486,4 & 263 & 5409 & 1550,1 & 287 & 30055 & 6299,2 & 210 & 109660 & 27335,7 & 249 \\
\hline \multicolumn{13}{|c|}{ Разом дубові насадження } \\
\hline Молодняки & 557 & 67 & 120 & 194 & 15 & 78 & 16511 & 1085 & 66 & 17262 & 1166 & 68 \\
\hline Середньовікові & 113241 & 30592 & 270 & 12922 & 3541 & 274 & 81961 & 19503 & 238 & 208124 & 53636 & 258 \\
\hline Пристиглі & 28082 & & 280 & 4574 & 1445 & 316 & 2117 & 649 & 307 & 34773 & 9959 & 286 \\
\hline Стиглі та перестійні & 21031 & 5006 & 238 & 2167 & 685 & 316 & 737 & 224 & 304 & 23935 & 5916 & 247 \\
\hline Усього & 162911 & 43530 & 267 & 19857 & 5686 & 286 & 101326 & 21461 & 212 & 284094 & 70677 & 249 \\
\hline
\end{tabular}

Дубняки в захисних лісах характеризуються таким розподілом насаджень за групами віку: середньовікові насадження $\epsilon$ найпоширенішими і ростуть на площі 64008 га (80,1% від загальної площі дубових лісів категорії), а їхній запас оцінено в 15957,6 тис. м ${ }^{3}(84,4 \%$ від загального запасу дубових лісів категоріі); стиглі й перестійні насадження та молодняки займають площу 6269 га $(7,8 \%)$ та 5113 га $(6,4 \%)$, а їхній запас становить 1368,4 тис. м $^{3}(7,2 \%)$ та 409,9 тис. м $^{3}$ (2,2\%) відповідно, а найменшу площу займають пристиглі насадження - 4526 га (5,7 \%), запас яких сягає 1164,0 тис. ${ }^{3}$ $(6,2 \%)$.

У категорії захисних лісів істотно за площею переважають дубові насадження порослевого та насіннєвого штучного походження, що займають площу 42906 га або 53,7 \% та 33173 га або 41,5 \% від загальної площі дубових лісів категорії відповідно. Дубові насадження насіннєвого природного походження займають площу 3836 га (4,8 \%). Розподіл загального запасу дубняків в межах захисних лісів є приблизно таким самим, як і за площею, але із дещо більшою часткою за запасом $(58,2 \%)$ дубових насаджень порослевого походження та меншою часткою (36,3 \%) дубових насаджень насіннєвого штучного походження.

Аналізуючи розподіл загальної площі дубових насаджень лісів природоохоронного, наукового, історикокультурного призначення, встановлено, що найбільшу площу займають середньовікові насадження - 31192 га (73,0 \% від загальної площі дубових лісів категорії), а їхній загальний запас сягає 8360,0 тис. м³. Значну пло- щу займають стиглі й перестійні та пристиглі насадження - 5113 га (12,0 \%) та 4894 га (11,4 \%), а їхній запас оцінено в 1227,2 та 1393,8 тис. м відповідно. Молодняки ростуть на площі 1530 га $(3,6 \%)$ із запасом 117,7 тис. $\mathrm{m}^{3}$.

Серед лісів природоохоронного, наукового, історико-культурного призначення за площею переважають дубняки порослевого (25596 га або 59,9 \% від загальної площі) та насіннєвого штучного (12135 га або 28,4 \%) походження. Дубняки насіннєвого природного походження ростуть на площі 4998 га (11,7%). Розподіл загального запасу дубняків у межах досліджуваної категорії лісів приблизно такий самий, як і за площею.

У рекреаційно-оздоровчих лісах також відзначено істотне переважання середньовікових насаджень, що ростуть на площі 89187 га (81,3 \% від загальної площі дубових лісів категоріi), а їхній запас становить 23171,1 тис. ${ }^{3}$ (84,8 \% від загального запасу дубових лісів категорії), пристиглі насадження займають площу 9086 га (8,3\%), а їхній запас сягає 2299,6 тис. м ${ }^{3}$ $(8,4 \%)$, стиглі й перестійні насадження - 6827 га $(6,2 \%)$ і 1575,9 тис. ${ }^{3}(5,8 \%)$ та молодняки - 4559 га $(4,2 \%)$ і 289,1 тис. м $^{3}(1,0 \%)$ відповідно.

Серед рекреаційно-оздоровчих лісів переважають дубняки порослевого (74196 га або 67,7\%) та насіннєвого штучного (30055 га або 27,4% від загальної площі) походження, а дубові насадження насіннєвого природного походження займають площу 5409 га (4,9\%). Подібним є розподіл загального запасу дубняків у межах рекреаційно-оздоровчих лісів. 
Загалом найбільшу частку дубових молодняків, зокрема, насіннєвого штучного походження, виявлено в експлуатаційних лісах, що пов'язано із переважанням суцільно-лісосічних рубок і подальшим створенням лісових культур на утворених зрубах. Це в майбутньому призведе до формування одновікових насаджень спрощеної структури, що не зовсім ефективно виконуватимуть важливі еколого-захисні та рекреаційно-оздоровчі функції. А, як відомо, до рекреаційно-оздоровчих лісів належать лісові ділянки, що виконують рекреаційну, санітарно-гігієнічну та оздоровчу функцію, використовуються для туризму, зайняття спортом, санаторно-курортного лікування та відпочинку населення і розташовані: 1) у межах міст, селищ та інших населених пунктів;

2) у межах округів санітарної охорони лікувально-оздоровчих територій і курортів;

3) у межах поясів зон санітарної охорони водних об'єктів;

4) у лісах зелених зон навколо населених пунктів;

5) поза межами лісів зелених зон, що виділяються за нормативами.

Подібну ситуацію необхідно змінювати способом активного запровадження вибіркових і поступових систем рубок головного користування в поєднанні із заходами сприяння природному відновленню дуба та догляду за ним. Варто також згадати, що до категорії експлуатаційних лісів належать лісові ділянки, що не зайняті лісами природоохоронного, наукового, історико-культурного призначення, рекреаційно-оздоровчими та захисними лісами (категорії лісів 3 особливим режимом лісокористування). Експлуатаційні ліси призначені для задоволення потреб національної економіки у деревині.

Висновки. Одними із найцінніших у лісовому фонді країни є дубові насадження, сучасний стан яких у більшості регіонів, зокрема, в Лівобережному Лісостепу, є незадовільним.

Дубові ліси регіону переважно зосереджені в рекреаційно-оздоровчих і захисних лісах (38,7 і 28,1 \% від загальної площі лісів відповідно), а тому виконують важливі водоохоронні, грунтозахисні, рекреаційні, санітарно-оздоровчі, гігієнічні, естетичні та інші природоохоронні функції.

В усіх категоріях лісів виявлено розбалансованість вікової структури дубових насаджень із істотним переважанням середньовікових та пристиглих насаджень, доволі значною часткою стиглих і перестійних насаджень та незначною часткою молодняків.

Розподіл вікової структури дубняків далекий від оптимального. Ця особливість $є$ важливою підставою для вживання лісогосподарських заходів, спрямованих на оптимізацію вікової структури, зокрема, комплексних рубок (у т.ч. рубок переформування) у середньовікових низькоповнотних насадженнях у лісах природоохоронного, наукового, історико-культурного, рекреаційно-оздоровчого і захисного призначення. Це сприятиме поступовому перетворенню одновікових у різновікові мішані багатоярусні насадження, склад і структура яких відповідатимуть необхідним критеріям, що висуваються для наближених до природного стану характеристик лісів.

Віднесення кожної окремої лісової ділянки дубових насаджень до певної категорії лісів зумовлює встановлення відповідного режиму лісокористування. Результати дослідження доцільно враховувати під час розроблення відповідних рекомендацій, впровадження яких сприятиме підтриманню складної багатоярусної структури дубових лісів, підвищенню їх продуктивності та посиленню виконання ними важливих екологічних, захисних і рекреаційно-оздоровчих функцій.

\section{References}

1. De Groot, R. S., Wilson, M. A., \& Boumans, R. M. (2002). Atypology for the classification, description and valuation of ecosystem functions, goods and services. Ecological Economics, 41(3), 393-408. https://doi.org/10.1016/S0921-8009(02)00089-7

2. Didenko, M. M., \& Poliakov, O. К. (2018). Стан природного поновлення дуба звичайного під наметом лісу в Лівобережному Лісостепу. Forestry and Forest Melioration, 132, 25-34. https://doi.org/10.33220/1026-3365.132.2018.25

3. Girs, A., Novak, B., \& Kashpor, S. (Ed.). (2005). Forest management. Kyiv: Aristey, 435 p. [In Ukrainian].

4. Hrom, M. M. (Ed.). (2007). Forest inventory. Lviv: RVV NLTU, 416 p. [In Ukrainian].

5. Hudyma, V. D., Parpan, T. V., \& Plikhtiak, P. P. (2018). Функціонально-цільова та вікова структура гірських лісів Українських Карпат. Forestry and Forest Melioration, 133, 71-77. https://doi.org/10.33220/1026-3365.133.2018.71

6. Johann, E. (2007). Traditional forest management under the influence of science and industry: the story of the alpine cultural landscape. Forest Ecology and Management, 249, 54-62. https://doi.org/10.1016/j.foreco.2007.04.049

7. Jonsson, R., \& Rinaldi, F. (2017). The impact on global woodproduct markets of increasing consumption of wood pellets within the European Union. Energy, 133, 864-878. https://doi.org/10.1016/i.energy.2017.05.178

8. Lunachevskyy, L. S., \& Rumiantsev, M. H. (2017). Effect of thinning intensity on the mensuration parameters of oak stands in fresh maple-lime oak forest in the Left-bank Forest-Steppe. $F_{O}$ restry and Forest Melioration, 131, 33-39. [In Ukrainian].

9. Meshkova, V. L. (2011). Dynamics of sanitary condition of oak stands in the Left-bank Forest Steppe of Ukraine after forest management operations. Forest journal, 1, 28-32. [In Ukrainian].

10. Pilli, R., \& Pase, A. (2018). Forest functions and space: a geohistorical perspective of European forests. iForest, 11, 79-89. https://doi.org/10.3832/ifor2316-010

11. Rumiantsev, M., Luk'yanets, V., Musienko, S., Mostepanyuk, A., \& Obolonyk, I. (2018b). Main problems in natural seed regeneration of pedunculate oak (Quercus robur L.) stands in Ukraine. Forestry Studies, 69, 7-23. https://doi.org/10.2478/fsmu-2018-0008

12. Rumiantsev, M. H., Lyk'yanets, V. A., Samoday, V. P., Ihnatenko, V. A., Sotnikova, A. V., \& Trophymenko, M. Ye. (2018a). Особливості попереднього відновлення господарсько цінних порід під наметом природних дубових лісостанів в умовах свіжої та вологої кленово-липової судіброви Лісостепу Сумщини. Forestry and Forest Melioration, 132, 35-40. https://doi.org/10.33220/1026-3365.132.2018.35

13. The procedure of division of forests on category and determination of protective forest areas. Cabinet of Ministers of Ukraine from 16.05.2007, № 733. Retrieved from: https://zakon.rada.gov.ua/laws/show/733-2007-\%D0\%BF.

14. Tkach, V. P., Kobets, O. V., \& Rumiantsev, M. H. (2019). Стан та продуктивність дубових насаджень степової частини України. Forestry and Forest Melioration, 134, 13-23. https://doi.org/10.33220/1026-3365.134.2019.13

15. Tkach, V. P., Kobets, O. V., \& Rumyantsev, М. Н. (2018b). Використання лісорослинного потенціалу лісами України. Forestry and Forest Melioration, 132, 3-12. https://doi.org/10.33220/1026-3365.132.2018.3

16. Tkach, V. P., Luk'yanets, V. A., \& Rumyantsev, M. G. (2014). Advance regeneration of tree species in fresh maple-lime oak forest of the Left-Bank Forest-Steppe. Forestry and Forest Melioration, 124, 47-54. [In Ukrainian].

17. Tkach, V. P., Luk'yanets, V. A., Tarnopylska, O. M., \& Rumyantsev, M. G. (2018a). Шляхи переформування порослевих дубових деревостанів Лівобережного Лісостепу, виключених 3 режиму головного користування. Forestry and Forest Melioration, 132, 48-56. https://doi.org/10.33220/1026$\underline{3365.132 .2018 .48}$ 
M. H. Rumiantsev

Ukrainian Research Institute of Forestry and Forest Melioration named after G. M. Vysotsky, Kharkiv, Ukraine

THE STRUCTURAL AND FUNCTIONAL DISTRIBUTION OF OAK STANDS OF LEFT-BANK FOREST-STEPPE ZONE

The distribution of the total area is covered with forest vegetation of forest sites within the territory of the Left-bank Forest-steppe zone for prevailing species was conducted on the basis of the materials on forest management (taxation database). The distribution of the area and stock of oak stands by categories of forests and their age structure in terms of origin were analysed. In the course of the research we identified, that the main forest forming species composition in the forests of the Left-bank Forest-steppe zone is varied and submitted with 70 tree species. Oak stands (Quercus robur L.) are the most common as they occupy $46.4 \%$ ( 284.1 thousand ha) of the total area is covered with forest vegetation of forest sites. Research findings suggest that the largest share of the total area of oak forests of the Left-bank Forest-steppe zone account for recreational forests - 38.7\% (109.7 thousand ha), slightly smaller $28.1 \%$ ( 79.9 thousand ha) there is a share of protective forests, and the share of exploitable forests, and also forests with conservational, academic, historical, and cultural purposes stands at $18.2 \%$ (51.8 thousand ha) and $15.0 \%$ (42.7 thousand ha) respectively. The distribution of the total stock of oak forests between categories of forests is almost the same as by the area. In all categories of forests it was noted imbalance of age structure of oak stands with a predominance middle-aged and premature stands, a very considerable share of mature and old growth stands and the limited share of young stands. The assignment of each individual forest site of oak stands to a certain categories of forests requires to establish an appropriate regime of forest management, especially for relevant forms of felling. In order to effective manage forests effectively, in particular, in the oak forests of the Left-bank Forest-steppe zone it can be useful to improve their age structure using their structural and functional distribution, which is defined according to their classification into relevant categories of forests.

Keywords: oak stands (Quercus robur L.); forest categories; stand origin; age groups; stand stock; materials on forest management. 